\title{
Convergence Education of Medicine and Theology in a Secular Age ${ }^{\dagger}$
}

\author{
Soo-Young Kwon ${ }^{1}$, Nam Hoon $\mathrm{Cho}^{2}$ and Moon Son ${ }^{1, *(1)}$ \\ 1 College of Theology, Yonsei University, 50 Yonsei-ro, Seodaemun-gu, Seoul 03722, Korea; \\ sykwon@yonsei.ac.kr \\ 2 College of Medicine, Yonsei University, 50 Yonsei-ro, Seodaemun-gu, Seoul 03722, Korea; cho1988@yuhs.ac \\ * Correspondence: sm0925@yonsei.ac.kr; Tel.: +82-10-7355-6732 \\ + This work was supported by the Ministry of Education of the Republic of Korea and the National Research \\ Foundation of Korea (NRF-2017S1A5A8022660).
}

Received: 27 September 2018; Accepted: 6 November 2018; Published: 15 November 2018

check for updates

\begin{abstract}
Convergence education of medicine and theology (CEMT) is an effective religious education learning model in a secular age. The highly elaborate rationality of the secular environment encourage es dialogical discourse between science and religion. There is a mutually reinforcing relationship between medicine and theology even given each discipline's differences from the other. In this paper, the dialogical discourse between medicine and theology about the human-genome project serves as an example of the symbiotic relevance of both disciplines. The Ebola virus shows how theological discourse can be included in what is apparently a medical concern to ultimately benefit medical efforts. An example of CEMT in the classroom shows the possibilities for enlarging the conventional horizons of religious education to overlap medicine.
\end{abstract}

Keywords: secularization; rationality; medicine; theology; symbiotic relevance

\section{Introduction}

This study focused on a new position for religious education in public educational life, such as in universities or higher education institutions through the convergence education of medicine and theology (CEMT) in a secular age when religious belief and practice are a declining part of public life, their specific tenets become generalized, and their values substituted for secular values [1]. CEMT can be understood at the level at which secularized religious beliefs obtain their moral legitimacy by becoming generalized [2]. This type of convergence project helps make innovative medical research more responsible by allowing diverse stakeholders to engage in inclusive decision-making regarding social and ethical conflicts about challenging issues, such as genetic modification [3]. For example, CRISPER is a recent new type of RNA-directed gene drive system that effectively allows for genetic synthesis [4]. Recently, however, a U.S. National Academy of Science working group identified this type of technology and warned of social and ethical problems that arise from experiments, even on germ lines through RNA-directed gene drives like CRISPR. Even Jennifer Doudna, a leading researcher who contributed the development of CRISPR, called for a "moratorium on gene editing in human embryos, including for research purposes" [5]. Even genetic researchers who support the promise of curing genetic diseases argue that genome-engineering technology should be encouraged and supported by the public trust through "ongoing transparency and open discussion" in scientific communities [6]. CEMT encourages learners to develop their ethical and moral awareness through the mutual interaction between their own worldviews, such as their religious beliefs, feelings, and attitudes and their lived human experience in terms of the high technology required for genetic engineering for human enhancement [7]. CEMT considers their academic difference and methodological distinctions 
from an interfaith perspective to respect and appreciate the other as transformative and as a form of provocative pedagogy [8]. This study explored the interdisciplinary co-operation of convergence curriculum between medicine and theology in the United Graduate School of Theology at Yonsei University in Seoul, South Korea during the spring semester of 2017, and examined graduate students' pedagogical paths that brought them to enroll in CEMT courses and whether they did so with the perspective of hoping to receive a new perspective on religious education in a secular age. CEMT will be a new teaching and learning model to encourage the rationality of religious education for the public in a secularized society.

\section{Dialogue between Science and Religion}

CEMT can provide the resources required to interpret dialogue between science and religion, because the probability of religious narrative in a secularized society may be enhanced with the help of scientific discourse. Alister E. McGrath is a Professor of Theology, Ministry, and Education and Head of the Center for Theology, Religion, and Culture at King's College, London. He holds doctorates from Oxford University in both natural sciences and Christian theology. He focuses on the fine-tuning of the universe from a natural-theology perspective. The fine-tuning of the universe refers to the delicately adjusted patterns of the universe. Natural theology is the concept that connects science and religion. He takes Christian theology as an interpretive framework. Christian theology may be a schema to connect nature with transcendental beings in Christian faith, such as God, Jesus, and the Holy Spirit. In his book, McGrath tries to connect "anthropic phenomena in the natural sciences" with the "apparent fine-tuning of the cosmos" [9]. He stated that the "life-bearing properties of the universe are highly sensitive to the values of the fundamental forces and constants of nature", and will provide the possibility to see a series of processes from the "initial conditions of the universe" until the creation of complex life from a single perspective [9]. For example, the existence of stars rests on several delicate balances between the different forces in nature, and so serves as evidence of the fine-tuning of the universe. His contribution is in his framework for understanding the universe, which provides a meaningful link between science and religion.

He uses the term "anthropic principle" to describe fine-tuned cosmological systems. This principle can be applied to biological situations to explain the existence of a "life-bearing universe" [9]. He nevertheless does not only depend on the fine-tuning of the universe as a proof of the Christian belief in God. He focuses on "the discussion and analysis of fine-tuning" itself in nature, which is related to the exacting nature of natural science [9]. A Trinitarian natural theology represents his concerns about contemporary dialogue between the natural sciences and Christian theology and the Christian academic community. A Trinitarian natural theology as the Christian vision of reality supports the existence of anthropic phenomena described through the cosmological constants for the emergence of life and articulates how the anthropic principle is realized in chemistry, biochemistry, and evolutionary biology. This theory represents his intention to focus on the harmonious relationship between the natural world as reality and the Christian faith which is reflected in the light of the natural world. In other words, through the anthropic principle, the natural sciences can be transformed into a hermeneutical narrative.

In A Fine-Tuned Universe, McGrath proposes that "human beings long to make sense of things", meaning that they want to understand the structure of nature, to find the causes of what happens around them, and "to reflect on the meaning of their lives" [9]. This desire reflects the human character and its desire to try to discern purpose and meaning around us. Here, human activities exploring nature may be understood as the human quest for meaning. He said that the quest for meaning is important for three main reasons. First, it stabilizes existence. Second, it works as a defense mechanism to the challenge of meaninglessness. Third, it is the subjective response to an objective reality. These three reasons correspond to the individual's attempts to realign their internal world. Human concerns about nature go beyond "questions of mere utility" and include witnessing "a deeper moral and intellectual order of things" [9]. His understanding of natural theology can also be interpreted as an attempt to 
find common ground for dialogue between the Christian faith and human nature. Natural theology also serves as a way to relate the Christian faith and the natural sciences. He treats the notion of nature as a social construction rather than an objective reality, so it must be reinterpreted in a new way. Moreover, he believes that science and religion are social constructs, as they depend on "the prevailing assumption of cultural and academic power groups" and are shaped by their historical, cultural, and political contexts [9].

Similar to McGrath's understanding, Freeman Dyson, a physical scientist, is also interested in how hermeneutical narratives can integrate science and religion. Dyson's book, Infinite in All Directions, is based on the Gifford Lectures given at Aberdeen in 1985 in which Dyson provided his opinions about the diversity of the natural world and the diversity of human reactions to it. Dyson regards "diversity" as "the chief source of beauty and value" [10]. He categorizes the scope of diversity as "the natural universe", "the governance of human societies", and "individual souls" [10]. Given all of the diversity in existence, Dyson argues that "God loves diversity" [10]. This statement is the positive foundation on which the value of diversity can be revitalized. Dyson's book includes his philosophical views about science and religion. He recognizes the difference between science and religion in the way that they explore. However, Dyson argues that these two ways of exploring show us the same universe, both theoretically and practically. Even though science and religion are not in conflict, they are limited and do not see each other at the same time. In the case of religion, he proposes William James' Varieties of Religious Experience as an example of diversity. He also says that "the total human consciousness of the divine" explains human nature's diversity as well [10]. In other words, diversity is the main way of exploring science and religion.

His concerns about religion and science are reflected in the term natural theology. He classified "natural theology" as being made up of "the Bible" and "the Book of Nature" [10]. For Dyson, God's works may appear in the Bible as well as the Book of Nature. This also reflects Sir Adam Gifford's will in "establishing the Gifford Lectures" [10]. He believed that we can read "God's mind" in "the works of Nature" [10]. This expression imbues great meaning into the works of nature. Dyson's understanding makes possible a theological approach to the natural sciences. Dyson states that "God did not only create mountains, he also created jungles" as a metaphor [10]. He equates "the great mountain peaks" with "Maxwell's equations of the electromagnetic field, Einstein's theory of general relativity", indicating that the mountains represent great academic works [10]. The jungles were "only obstacles to be overcome" in the past [10]. Today, Dyson stresses on the importance of the jungles in passages such as the following:

But God did not only create mountains, he also created jungles. And today we are beginning to understand that the jungles are the richest and most vibrant part of his creation. The mountain explorer in South America or in Africa is not looking for mountains. She is looking into the depths of the jungles to observe and understand the creatures who live there in all their intricate variety. We ourselves came out of the jungles a few million years ago, and we are now becoming aware that we need to understand and preserve the jungle if we are to remain alive and healthy on this plant. [10]

Here, we can find that the great scientific findings are portrayed as both the mountains as well as the jungles. In the past the jungles were regarded as the obstacles to be overcome. But now, the jungles can be understood as a great treasure that helps life to survive and thrive on Earth. There is a great paradox in the shift of our perspectives from valuing mountains to jungles. Dyson continues to explain this transformation with the great changes in physics:

After we began seriously to explore the valleys in the 1950s, we found in them flora and fauna as strange and unexpected as anything to be seen in the valleys of the Amazon. Instead of the three species of elementary particle (proton, neutron, and electron), which were known in the 1920s, we now have sixty-one. Instead of a few succinct equations to summarize the universe of physics, we have a luxuriant growth of mathematical structures, as diverse 
as the phenomena that they attempt to describe. So we have come back to the rain forest, intellectually as well as geographically. [10]

Dyson attempts to transform the philosophical lessons in the recent discoveries in physics regarding the understanding of matter. In Dyson's metaphor, the period during which the mountaintops were the focus was organized around a worldview in which there was "an objective world of space and time" and "matter independent of human thought and observation" [10]. However, Dyson's scientific conclusion is that such a worldview is impossible today. Dyson points out that Einstein's hope about an "objective reality" being understood through "a finite set of equations" is a relic of the past [10]. Likewise, the new consensus about matter allows for a transformation of the relationship between religion and science, such as allowing for the possibility of interpretive narrative for understanding matter, such as quantum horizons. Dyson says, "when we examine matter in the finest detail in the experiments of particle physics, we see it behaving as an active agent rather than as an inert substance" in quantum mechanisms, which provides a new perspective on religion as well as science [10].

McGrath and Dyson emphasize the harmonious elements of the dialogues between religion and science. However, it is difficult to capture "the inter-relationship between beliefs and the wider philosophy of nature" only in a perspective [11]. Even though religious scientists, "like Boyle, Newton, or Maxwell", stressed the harmonious dialogues between "a Christian view of the world" and "the real world", the differences between each should be recognized [11]. When these differences and the importance of creative analogies in the relationship between religion and science are recognized, the productive meanings that bridge the gap between "the influence of observers" and "the outcomes" of physical reality as the creative and organic relationship between the nature and human beings as it is observed can be understood [12]. Likewise, CEMT creates a holistic combination of religion and science through narrative rather than through the distinctive factors of each discipline. The integrative narrative of CEMT encourages a new method of religious education for reinterpreting the rooted bases of religious traditions through interconnected and mutual dialogues with medicine, which is recognized as the fruits of the rationality of a secular society.

\section{The Human-Genome Project and Religious Education}

This section explores the integration of the human-genome project, regarded as the foundation of molecular medicine, with its theological implications at a narrative level. Powerful new genome-editing technologies, such as "CRISPER-Cas9, zinc fingers, and TALENs", have made it possible for molecular biologists to "insert, remove, and edit genes in cells-including sperm, eggs, and embryos" to cure "genetic disease" and develop "desirable traits" [13]. CRISPER in particular is the newest type of RNA-directed gene-drive system to synthesize genes [4]. However, a U.S. National Academy of Sciences working group recently pointed out the potential risks of that gene-drive technology and warned of the serious problems associated with using it to experiment on germ lines through. Even Jennifer Doudna, a leading researcher who contributed to the development of CRISPR, has called for a "moratorium on gene editing in human embryos, including for research purposes" [5]. The medical use of gene-drive editing technologies like CRISPR is related to organ transplant, which could be facilitated by inserting human genes into pigs or other animals. With regard to this procedure, researchers have raised the ethical issue of whether human genes would bestow some level of personhood on the animals. This type of ethical issue requires a Christian theological response and provides a new possibility for Christian religious education in a secular society. Here Christianity serves as one example for developing a new pattern of religious education. If this integrative narrative about genome technology and the Christian tradition can be understood by the public, it may be expanded to include other religious traditions. Many leading molecular biologists and physicians have recognized that recent gene-drive technologies are insufficient for modifying germline cells like sperm, eggs, and embryos. For example, in an experiment in which CRISPR was used to edit the genes of monkey embryos, the miscarriage rate was over $50 \%$, and even the products of successful pregnancies 
carried disease genes [13]. Gene-drive technologies like CRISPR shows that the technology exists, but that the ability to control its associated problems and risks does not. In this respect, the ethical issues raised by gene drive technologies provide a context for theological discourse for present and future generations. Moreover, Christian education can be reformed to originate in the cross-thinking interdisciplinary foundation between recent biological research and Christian insight.

Christians perceive human beings as having a "divine image and likeness" (Gen. 1:26). In Orthodox Christian theology, the true nature of the human mind and body are experienced in depth of the "deification" transformation that occurs through God's "will" and "energy" in participatory unity with God [14]. In other words, the concept of deification is defined as educational perfection or achievement of the wholeness of the human character. Therefore, the educational process for achieving and growing human spiritual character is strongly related to deification as the "ultimate aim" of "human existence" [15]. Traditionally, the Christian perspective has been focused on the "linear development" of the human beings' autonomous egos (Johnson, 1989, p. 109). For example, in the context of educational assessment, some evaluators used to focus on each person's capacity or achievement rather than recognize the comprehensive resources of their character. However, the Christian educational process naturally focuses on the comprehensive resources that come to bear during the process of Christian spiritual formation of the human being. The relationship between Christian education and the recent scientific achievement of developing genetic engineering technologies, such as CRISPR, is considered from this perspective. It is not easy to directly link many genetic-engineering issues with traditional Christian sources. However, religious educators have the ethical and normative duty to help their students reflect on their own worldviews, such as Christian "beliefs, feelings, and attitudes", during their "lived human experience" [7]. In other words, the basic framework for Christian education in the postgenome era could be formed through the process of responding to some ethical issues raised by the high technology of genetic engineering in relation to human enhancement. The hermeneutical integration between Christian theology and genome technology provides a plentitude of meaning which can extend the horizon of human enhancement. Such progress includes purposeful and existential orientations in human growth.

The main factor of Christian education is the search for the transforming moment of human character, which is when a believer has a "convictional experience," unique in their entire existence [16]. From the Christian perspective, the transforming growth or development of human beings can be conceived in terms of communion with God in the world, such that the Eucharistic theology of Orthodox Christianity emphasizes the spiritual dependence on God as "a sacrament of communion with God" [17]. Schmemann places the theological meaning of the Eucharist on the bilateral relationship between natural and supernatural frameworks, sacred and profane meanings, and the spiritual and material [17]. Here, the core of Eucharistic life is the moment of transformation from a life grounded in the material world to a spiritual and meaningful "life in God" [17]. The Eucharistic life can be concretely understood through "the Chalcedonian definition on the two natures of Christ" [14]. The divinity of Christ and His humanity are each different parts of his nature, but each part can be hypostatically united as "being in 'communion' with each other" [14]. This hypostatical unity of the two natures of Christ is symbolized by the complementary existence of the body and soul in humans. The nature of death in particular can be understood as the "separation between body and soul" [14]. The church's liturgical activity in the Eucharist naturally emphasizes the harmonious balance between the spiritual and the material, but does so against foundational orientations to "make the world material" [17]. The other transforming element of the Eucharist is the activity of the Holy Spirit to realize the eschatological character of the world. Thus, Schmemann argues that the Eucharist as communion in the Holy Spirit is an initiative to transform "the Church into the body of Christ" [17]. In sum, the Eucharistic self of human beings can be symbolized by the hypostatically ordered relationship between divinity and humanity, natural and supernatural frameworks, sacred and profaned meanings, and the spiritual and the material. Sometimes, the historical division of the one true Church can therefore be understood as grievous impoverishment on the human level [18]. 
Recently, those working with the high technology of genetic engineering have needed to consider the ethical involvement of "human germline genome editing" and how it can cause a "disease-causing genetic mutation" in its DNA sequencing [6]. The genetic researchers who support promising efforts to cure genetic disease argue that it is "the recombinant DNA era", and that genome-engineering technologies for human and nonhuman models should be encouraged and supported by the "public trust" through "ongoing transparency and open discussion" in scientific communities [6]. Sara Reardon [19] presented various cases in which editing technologies were used as medical treatments, including a one-year-old girl with leukemia, 12 people with HIV, and people with a rare retinal disorder. Human applications of gene-editing technologies outside of the human germline are now used to treat many different conditions. Usually, the results of natural scientific experiments are strongly applicable to human beings as well as the nonhuman subjects on which they are conducted. For example, a technique for editing monkey genes to cause them to produce blood-clotting proteins may be able to be used directly in human gene-editing medical treatments [19]. However, Christians understand human beings as "hypostatic beings" who are "created in the divine image" [20]. The difference between human beings and nonhuman creatures can be found in the hypostatic orders of each, which can be understood as fundamental and a framework for responding to the scientific community's persistent efforts to discover applications for human germline genetic engineering. The Christian ethical framework is morally meaningful in that it provides a theological foundation for recognizing the hypostatical difference between human being and nonhuman creatures for the issue of human germline genetic engineering [21]. Thus, the Christian church, with the addition of some rational frameworks, possesses the spiritual and ethical resources to discern which outcomes are ethically appropriate in the ambiguous ethical challenges of medical issues. In other words, theological clarity and boundaries of ethical activity can be determined.

The Christian perspective has the "moral and spiritual legitimacy" to respond to genetic editing technology challenges, including those associated with human germline genetic engineering [21]. The Christian framework consists of "ecclesial, communal, and relational" resources [22]. The Eucharist as the ontological sacrament of salvation in Christian theology entails the "otherness of the whole church" [22]. For example, such otherness includes the social and moral impact that "the technique on human reduction" naturally provides [23]. Human genetic modification requires a theological response to define human nature in the context of the ethical challenges that such otherness delivers. Influential human-genome project researchers have also emphasized "responsible innovation" to enable diverse stakeholders with their own social and ethical frameworks to engage in "inclusive decision-making" about challenging genetic-modification issues [3]. In this context, the Eucharistic self symbolizes the inner system of the consciousness of the faithful to construct the otherness which genetic modification provides in an orderly fashion. The Eucharistic self may be the theological narrative for connecting genetic engineering and "transcendental values and concerns" [24]. If the tradition of public theology is considered as interpreting "religious truth" in the framework of the "common good" [25], the parallels between Christian thought and responsible genetic-engineering innovation might encourage living transformation "from love of self and the world and to God and neighbor" [26]. The link that Christian education provides between Christian theology and medical science can be seen in the way that the Eucharistic self is taught to arrive at the path of salvation toward deification through the deep challenges presented by genetic modification. If the focus of CEMT is the theological interpretation of the human-genome project with an emphasis on the balance between medical and theological narratives, the next section focuses on how medical narratives such as those regarding the Ebola epidemic can be interpreted to have theological implications.

\section{Ebola Virus}

In late September 2014, the statistics about the West African Ebola were terrible. According to the data of the World Health Organization (WHO) released on September, 2014, 648 people had died among 1074 Ebola-infected people in Guinea, 1830 people had died among 3458 Ebola-infected people 
in Liberia, 605 people had died among 2021 Ebola-infected people in Sierra Leone, eight people had died among 20 Ebola-infected cases in Nigeria, and 23,375 healthcare workers across four West African countries (Guinea, Liberia, Serra Leone, and Nigeria) and 211 people among them had died [27]. Historical data about Ebola outbreaks from 1976 to the present show just how terrible the 2014 West African Ebola was. Figure 1 compares the 2014 West African Ebola outbreak and other sub-Saharan outbreaks from 1976 to 2012. A total of 814 Ebola infections occurred in the five months between March 2014 to July 23, 2014. As of September 2014, the 2800 cases of the Ebola outbreak were greater than the 1550 Ebola infections that occurred between 1976 and 2012. The 2014 outbreak was the most serious outbreak in history and "shows no sign of abating" [28].

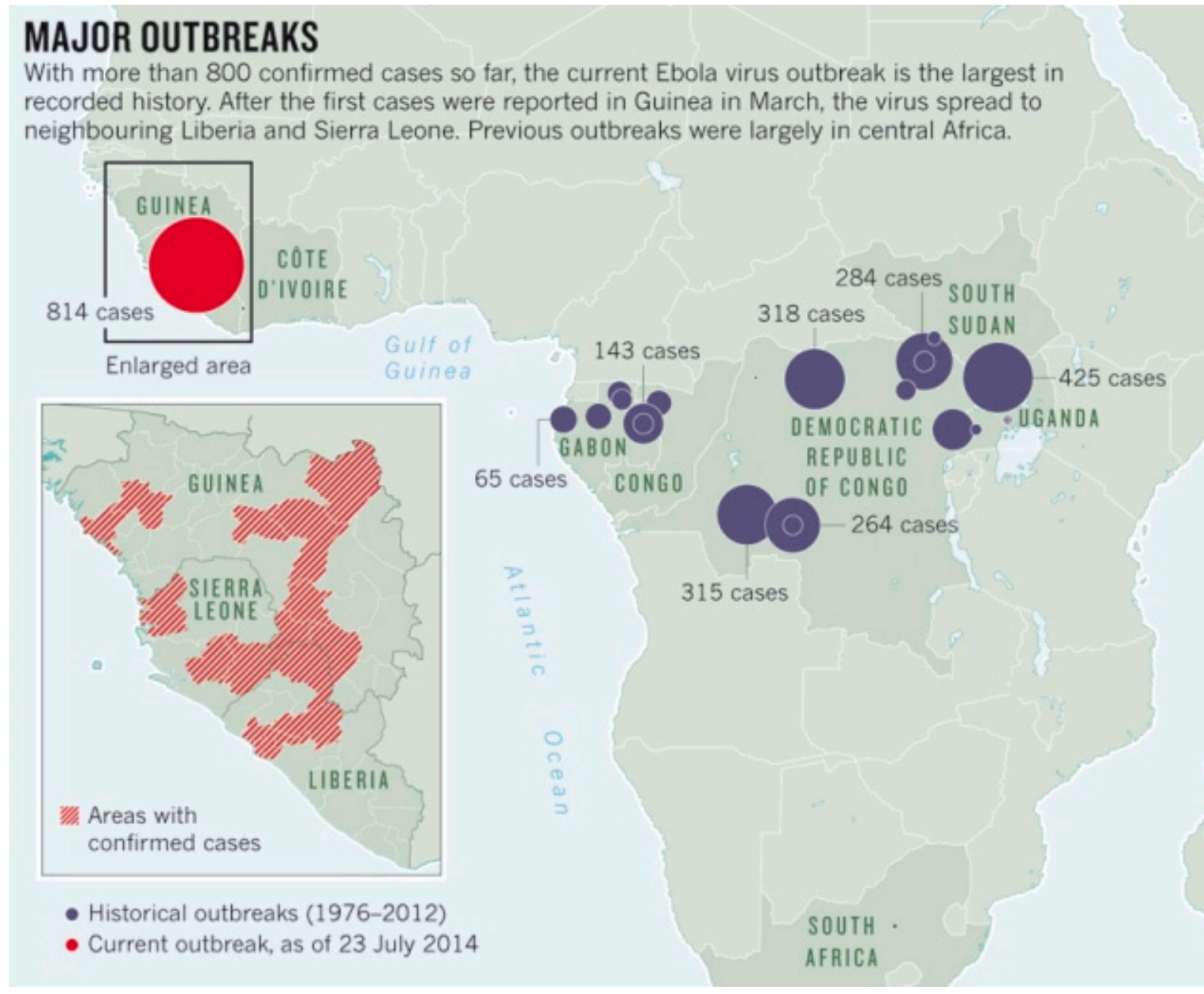

Figure 1. Ebola virus outbreaks by Sarah Reardon [28].

Medical workers in West Africa had to battle a rapidly growing Ebola outbreak, insufficient medical resources, and rumors that they were harvesting patients' organs and conducting medical experiments on them [28]. In response, medical workers had to isolate infected people, separate them from their families, and educate "the public on how to avoid spreading the disease" [28]. The Ebola outbreak was so serious because there were no drugs or vaccines that had been approved by regulators to treat the disease. The 2014 Ebola outbreak could fairly be characterized as "out of control" (Figure 2). On 25 March 2014, the WHO reported an outbreak of Ebola in Guinea in West Africa. On 20 June 2014, Medicins Sans Frontieres said that the outbreak was "totally out of control" [29]. On 4 August 2014, the World Bank pledged up to US\$200 million to contain the outbreak. On 8 August 2014, the WHO declared that the outbreak was a public health emergency that should attract international concern. However, as Hayden's graph shows "the death toll from Ebola virus in West Africa continued to rise" [29]. With insufficient medical facilities in West Africa, medical workers' 
strikes, isolated patients, uprisings by the uninfected, and the insensitivity of government officials to the importance of conducting comprehensive follow-ups for disease-control and -prevention efforts provided more serious problems. For example, the U.S. Centers for Disease Control and Prevention in Atlanta, Georgia sent 60 people to West Africa. They were not healthcare workers and experts, as their main tasks was to carefully watch track the development of Ebola and educate the public about the situation [29]. Last Mile Health, a nonprofit organization that operates out of Boston, Massachusetts, also sent "150 community health workers to educate rural Liberians about Ebola" [29].

\section{OUT OF CONTROL}

The death toll from Ebola virus in West Africa continues to rise. Infectious-disease experts say that more health-care workers are needed to contain the outbreak.

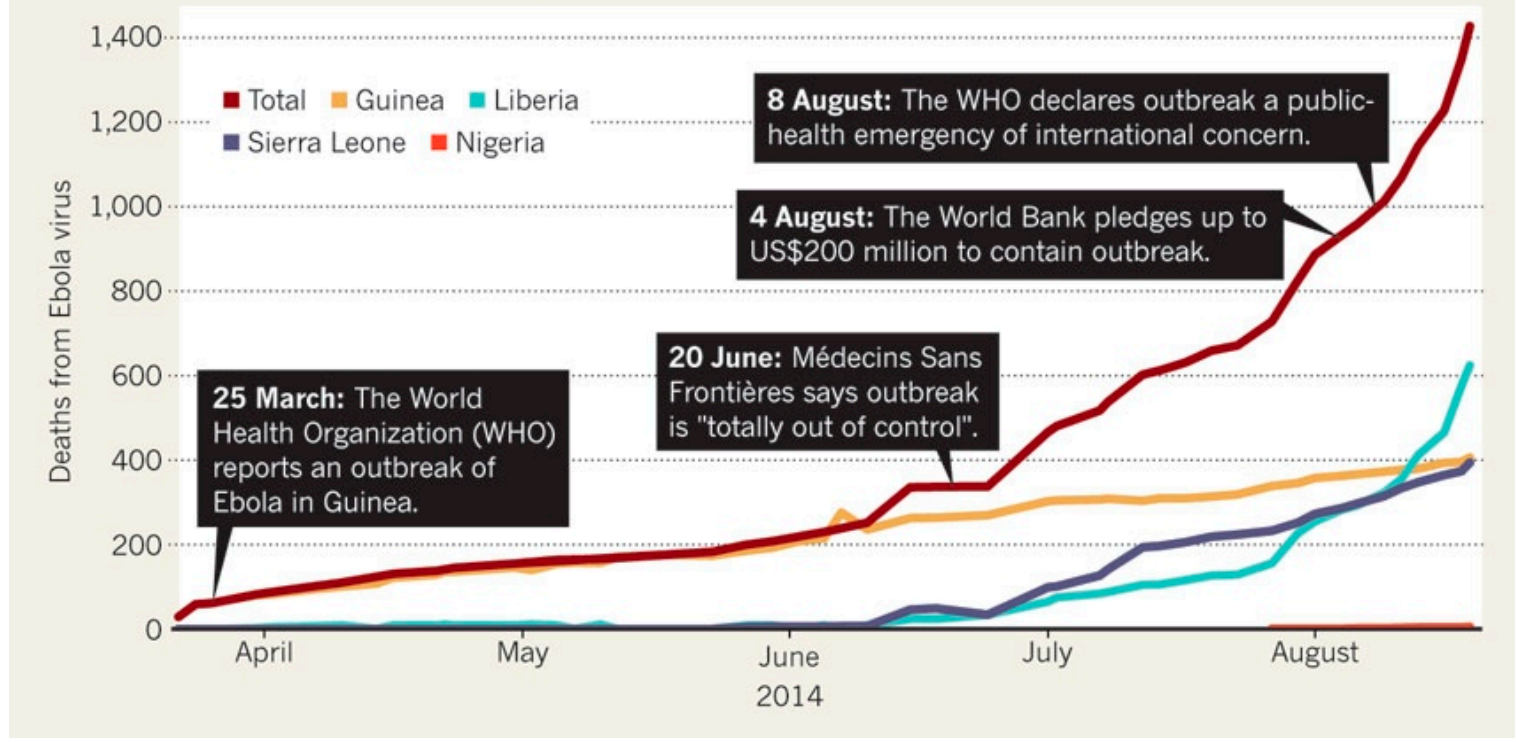

Figure 2. Death toll from the Ebola virus outbreak in West Africa by Erika Chek Hayden [29].

The terrible Ebola outbreak gave rise to the new term "compassionate use", which describe the "use of unapproved drugs and vaccines" to help Ebola patients. For example, although "no drugs or vaccines for Ebola have been approved by regulators", Mapp Biopharmaceutical of San Diego, California, prescribed doses of ZMapp to at least seven people [30]. In August 2014, "an expert panel convened by the WHO concluded unanimously that it is ethical to use unapproved drugs and vaccines" to help control this Ebola outbreak [30]. The WHO itself recognized that the urgency of the Ebola outbreak meant that there was not to have enough time for clinical trials for "testing drugs and vaccines" in humans "outside of an epidemic setting" [30]. Even though there were several Ebola vaccines and treatments, due to "a lack of funding and of international demand," they had not been subject to clinical trials to test these in humans outside of an epidemic setting [28]. Of the Ebola vaccines and treatments, the WHO recognized the use of ZMapp for treating Ebola. ZMapp inactivates the Ebola virus through a cocktail of antibodies. However, ZMapp has not received regulatory approval and has not been subject to clinical trials to test it in humans outside of an epidemic setting. ZMapp has shown surprising effectiveness in test on nonhuman primates. All of the "rhesus macaques" which were infected with the Ebola virus were still alive five days after having received ZMapp, as shown in Figure 3 [31]. Medical ZMapp trials have demonstrated "substantial benefits" in nonhuman primates.

Ebola virus infections cause severe illness in humans and nonhuman primates. Its initial symptoms are similar to those of the common flu. However, "after an incubation period of three to 21 days", the disease progresses rapidly and generates internal hemorrhaging, "multiple organ failure," "a shocklike syndrome", and then death [31]. Scientists found a new Ebola variant in the West Africa country of Guinea in spring 2014. Since March 2014, the Ebola outbreak spread dramatically 
throughout Guinea, Sierra Leone, Liberia, and Nigeria, and the death toll showed no signs of leveling off. Medical workers managing the Ebola outbreak provided patients with the latest medical care and used "barrier methods to prevent transmission" without proper vaccines or drugs except ZMapp, as it was approved for "compassionate use" [30,31].

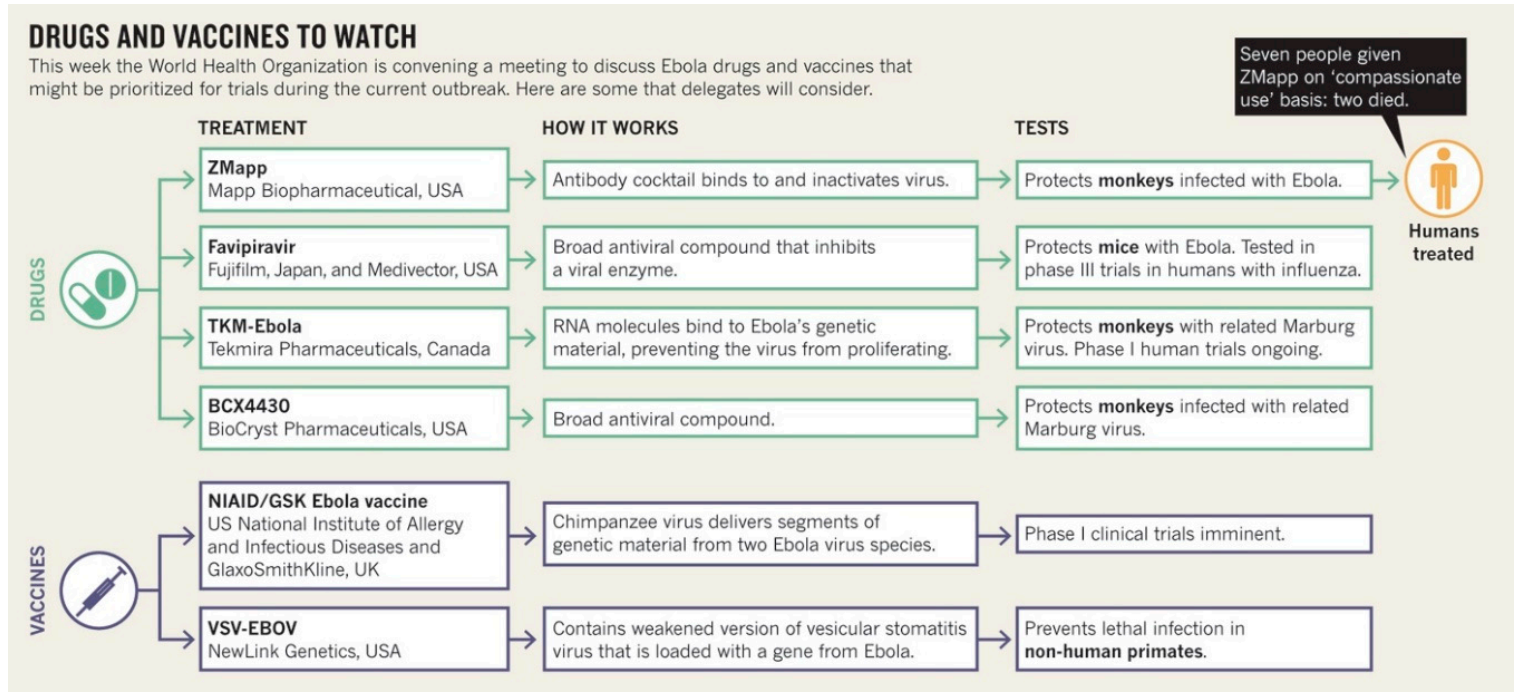

Figure 3. Ebola drugs and vaccines by Declan Butler [30].

According to the description of Ebola virus in the McGraw-Hill Encyclopedia of Science and Technology, 10th edition, the Ebola virus contains "a single species of ribonucleic acid (RNA) molecule" in a single, linear, nonsegmented strand and a shepherd's crook. The Ebola virus's RNA-protein complex on the surface of its cell membrane is, in turn, synthesized by "the outer membrane of infected cells". The Ebola virus then penetrates the cell and freely spreads "the genetic information contained in the RNA molecule" within the cell's cytoplasm. Through cellular machinery, the Ebola virus synthesizes "new viral proteins and RNA". "Ebola virus RNA polymerase (L)" may facilitate this cellular machinery in synthesizing new viral proteins and Ebola virus RNA (Ebola virus disease-Wikipedia). In this context, the polymerase refers to any enzyme that facilitates the synthesis of DNA or RNA. Thus, the development of Ebola drugs and vaccines focuses on delivering "an optimized antibody combination" to inactivate any enzyme, such as the "Ebola virus RNA polymerase (L)" to promote the synthesis of new viral proteins and Ebola virus RNA [31].

RNA is a chemical that is similar to DNA in structure. It contains the same nucleotides as DNA. However, RNA uses the pyrimidine uracil in the place of thymine of DNA. Therefore, RNA can "contain information" and also forms a "double helix" just like DNA [32]. However, unlike DNA, RNA is made up of only a single strand. Usually, genetic information flows from DNA through RNA to proteins. The flow from DNA to RNA is called "transcription" and the flow from RNA to proteins is called by "translation" [32]. Each strand of the DNA double helix has different genetic functions. The right-hand side of DNA is called "sense" and is "used to make proteins", and the left-hand strand of DNA plays a critical role in conveying genetic information out of the nucleus [32]. In terms of "a single-stranded messenger RNA molecule" like "a half ladder", DNA information moves from "the nucleus of the cell (the information storehouse) to the cytoplasm (a highly complex gel mixture of proteins, lipids, and carbohydrates) [33]." This pattern of RNA shows well its role in transmitting DNA's genetic information. In other words, such a procedure is the foundation of genetics. The virus infection process operates in reverse. Scientists have discovered an enzyme that promotes the transformation of RNA into DNA. This reverse process is known as "reverse transcriptase", which "plays a key role in the way that certain viruses infect cells" [32]. RNA viruses such as HIV, which causes AIDS, called "retroviruses", use "reverse transcriptase" to insert their genetic information into the cell's own DNA [32]. The Ebola RNA polymerase with reverse transcriptase infects normal cells like 
retroviruses. However, the "DNA copies of RNA-based viruses" are critical to the incorporation of the "primate germline" as a device for sending DNA messages [32]. That information is important to those battling Ebola outbreaks. Perhaps the truly serious terror may be humans' horror rather than the Ebola outbreak itself. The significance of human horror provides the possibility of theological suggestion in these types of medical narratives. The 2014 Ebola outbreak shows how numerous medical cases can be transformed into CEMT subject matter through the theological construction narrative process.

\section{Co-Operation and Human Disease}

This section explores the concept of co-operation between medicine and theology. This conceptual framework of co-operation encourages the creation of CEMT inventory. Coakley and Nowak define co-operation as "a form of working together" [34]. They also include the condition of fitness, which they define as a situation in which "one individual pays a cost" and "another gains a benefit as a result" [34]. This fitness is brought about in proper genetic or cultural conditions. Shared goals among members determine the orientation of co-operation. The relationship between co-operation and altruism is important in Coakley's research. She regards altruism as "a subset of co-operation" [35]. Coakley and Nowak say that "altruism is a form of (costly) co-operation in which an individual is motivated by goodwill or love for another (or others)" [34]. Coakley likely recognizes that evolutionary co-operation and altruism have some similarities.

Coakley says that co-operation is during "'construction': in the genome, in cells, in multicellular organisms, and in animal and human societies" [35]. She says animals and humans cooperate for some benefit. Thus, particular circumstances may serve as the origin for co-operation about a crucial matter. Whether co-operation is rational is determined by whether it produces a benefit. Thus, co-operation depends on self-interest and so is different from pure altruism. Likewise, self-interest and altruism create a dilemma about the conditions of co-operation. Nowak's five conditions for co-operation provide a meaningful solution to this dilemma: kin selection, direct reciprocity, indirect reciprocity, spatial selection, and group selection. Coakley says that "co-operation' can attain an evolutionary stable state" under these five conditions [35]. The main purpose of this study was to explore co-operation under these conditions.

In order to better understand the five co-operative mechanisms, a distinction must be made between co-operation and defection. Given the "human trait of intentionality in co-operative acts" from "the hierarchy of evolution" perspective, co-operative behavior can be described in terms of costs and benefits. In addition, the definition of altruism includes "goodwill or love for another" [35]. These descriptions include the general definitions of co-operation and altruism. It can be assumed that Coakley treated co-operation and altruism interchangeably in her lecture. Co-operation is a mechanism for construction. Co-operation naturally appears when any structure is constructed. Darwin provides persuasive descriptions about mutation and selection in the process of evolution, but he did not provide any descriptions of how co-operation might have evolved. Martin Nowak filled this gap. The Prisoner's Dilemma is another classical platform about rational choice in relation to co-operation. It is a hypothetical situation about two prisoners, A and B, who are separate from one another in different cells. The prisoners are aware that the police do not have enough evidence to convict them for a greater crime, but would have enough if one of them confessed, though they do have enough to convict each for a lesser crime. The police present the following three possibilities to each prisoner (Table 1):

1. If $\mathrm{A}$ and $\mathrm{B}$ both confess to having committed the crime, each of them will serve two years in prison.

2. If A confesses but B denies the crime, A will be set free, whereas B will serve three years in prison, and vice versa.

3. If both A and B do not confess, both of them will only serve one year in prison. 
Table 1. The Prisoner's Dilemma (Wikipedia).

\begin{tabular}{ccc}
\hline & Prisoner B Stays Silent (Cooperates) & Prisoner B Confesses (Defects) \\
\hline \multirow{2}{*}{ Prisoner A stays silent (cooperates) } & A serves one year & A serves three years \\
B gerves one year & gree \\
\hline \multirow{2}{*}{ Prisoner A confesses (defects) } & A goes free & A serves two years \\
& B serves three years & B serves two years \\
\hline
\end{tabular}

The rational choice is that both A and B defect and confess. Each prisoner knows that the other may confess and so are obliged to confess rather than stay silent to minimize the amount of time they spend in prison. The Prisoner's Dilemma shows that defection can be the more rational choice than co-operation. This dilemma is emblematic of human selfishness. Nowak's study about the mechanisms of co-operation demonstrate how organisms can overcome their selfishness to behave altruistically. Coakley assumes that the mechanisms of co-operation are sufficient to help organisms reach "an evolutionarily stable state" [35]. These mechanisms operate in five particular conditions: kin selection, direct reciprocity, indirect reciprocity, spatial selection, and group selection.

Kin selection is the first situation in which co-operation occurs. It refers to the co-operation that occurs between genetic relatives which tend to engage in mutual protection. In other words, kin selection is evolutionary evidence of co-operation. If kin selection exhibits co-operation between genetic relatives, then direct reciprocity is co-operation between unrelated individuals. Repeated interactions between unrelated individuals in the long term provides for a stable evolution. Nowak describes this mechanism as "generosity" and "evolution of forgiveness" [35]. Conditions for these interactions are those "certain circumstances in which the overall benefit (of co-operation) is greater than the cost (of co-operation)" [35]. Direct reciprocity shows that co-operation is a stable condition in the process of evolution. Indirect reciprocity is co-operation that occurs between people who may never meet again. The best-known example of indirect reciprocity may be the story of the Good Samaritan. Jesus tells this story when an expert in the Law of Moses asks him who his neighbors are.

Jesus replied: As a man was going down from Jerusalem to Jericho, robbers attacked him and grabbed everything he had. They beat him up and ran off, leaving him half dead. A priest happened to be going down the same road. But when he saw the man, he walked by on the other side. Later a temple helper came to the same place. But when he saw the man who had be beaten up, he also went by on the other side. A man from Samaria then came traveling along the road. When he saw the man, he felt sorry for him and went over to him. He treated his wounds with olive oil and wine and bandaged them. Then he put him on his own donkey and took him to an inn, where he took care of him. The next morning he gave the innkeeper two silver coins and said, 'Please take care of the man. If you spend more than this on him, I will pay you when I return' Then Jesus asked, 'Which one of these three people was a real neighbor to the man who was beaten up by robbers?' The teacher answered, 'The one who showed pity.' Jesus said, 'Go and do the same!' (Luke 10: 30-37)

The impactful element of this story is how it makes those who hear it feel. The story illustrates the normative principle that people should help anyone in terrible or difficult circumstances. It also puts those who hear it in the position of a priest, the temple helper, or the man from Samaria. That is the power of the story. If they helped, they would be praised. If they did not help, they would be blamed. Likewise, reputation is the most important requirement for indirect reciprocity. Reputation is a byproduct of language as it allows one's behavior to be observed by others removed from the situation. Human societies have evolved to give rewards for good behavior. In this situation, reputation is the main principle for initiating co-operation between humans. In other words, indirect reciprocity is a product of human language. This situation reflects the fact that co-operation is the remarkable product of natural selection.

Spatial selection and network reciprocity are interchangeable concepts. Coakley points out that co-operation is more natural and effective than defection in well-mixed populations, "because 
co-operators here form clusters which protect and enhance the success of their co-operation" [35]. The main point of "group selection" is to compare "groups of co-operators" with "groups of defectors" [35]. Group selection grants a higher probability of survival to co-operator groups than to defector groups. In other words, group selection focuses on the competition between the co-operator and defector groups. Natural selection selects for co-operator over defector groups. The difference between "spatial selection" and "group selection," the remaining conditions, is decided by the pattern of competition. Spatial selection refers to competition between individuals, while group selection refers to competition between groups. The Prisoner's Dilemma demonstrates that "defection' always gives higher 'payoffs' as an initial 'strategy'" [35]. Here, the value of the payoff is different between the benefit and cost of a given action. In this situation, Nowak and Coakley's project provides a logical foundation for why evolution would nonetheless favor co-operation. The descriptions of the five conditions under which co-operation occurs provide evolutionary explanations for how natural selection can produce co-operation. For example, Coakley's idea that cancers are "examples of uncontrolled cellular 'defection' causing the breakdown of an organism" proves that Nowak's mathematical approach of co-operation can be applied to a wide variety of circumstances.

The final task is to understand the concept of "inclusive fitness" [35]. The concept of "inclusive fitness" transcends the definition of the limitation of co-operation to depend on the sensitive relationship between "cost" and "benefit" [35]. For example, the issue of "inclusive fitness" is clear in the "evolution of eusociality" [35]. Eusociality is the highest level of organization of animal society and is characterized by co-operative brood care. The most familiar examples of eusocial insects are ants and bees. Individual worker bees sacrifice themselves for the sake of the queen bee. This behavior is an example of bees co-operating. However, it may be impossible to account for such co-operation by analyzing the situation according to just "cost" and "benefit." Coakley argues that "a bee population should be regarded as an organic whole" with different parts of "a body, an arm, or a leg" [35]. Coakley's description calls to mind Paul's reflection on the "mystical" body of Christ in 1 Corinthians 12:

A body isn't really a body, unless there is more than one part. It takes many parts to make a single body. That's why the eyes cannot say they don't need the hands. That's also why the head cannot say it doesn't need the feet. In fact, we cannot get along without the parts of the body that seem to be the weakest. We take special care to dress up some parts of our bodies. We are modest about our personal parts, but we don't have to be modest about other parts. God put our bodies together in such a way that even the parts that seem the least important are valuable. He did this to make all parts of the body work together smoothly, with each part caring about the others. If one part of our body hurts, we hurt all over. If one part of our body is honored, the whole body will be happy. Together you are the body of Christ. Each one of you is part of his body. (1 Corinthians 12: 19-27)

\section{CEMT at Yonsei University}

The final section discusses CEMT at Yonsei University in Seoul, South Korea. This case study shows the distinctive differences between medical science and theological understanding and has significant meaning as an example of CEMT in use. Yonsei University was the first Christian educational institution in South Korea and started with the establishment of Gwanghewon, the first modern hospital in Korea and the parent of Severance Hospital, in 1885. Severance Union Medical College and Yonhi College merged in 1957 to create Yonsei University. The creation of Yonsei University itself was a product of the convergence between medicine and other academic disciplines. College of Theology Professor Soo-Young Kwon and College of Medicine Professor Nam Hoon Cho opened the CEMT in the United Graduate School of Theology at Yonsei University in Seoul, South Korea during the spring 2017 semester in which 22 graduate students enrolled. In that course, Kwon enumerated Browning's five practical theological perspectives for convergent insights between medicine and theology: responsible borrowing, dialogue, areas of overlap, hybrid, and interstices [36]. 
These perspectives recognize the differences between medical science and theological understanding and encourage a hermeneutical dialogue between and the possibility of convergence of both academic disciplines. That course consisted of three board topics: life and birth, disease and suffering, and death and resurrection.

With regard to life and birth, Professor Nam Hoon Cho pointed out that medical knowledge can explain phenomena such as male sex determination, maternal inheritance, carrier and genetic disorders, genomes and phenotypes, crossing-over during meiosis, egg fertilization from ovulation to implantation (Figure 4), genetic differences between males and females, sexual determinants (i.e., chromosomal sex, gonad sex, duct sex, genitalia sex), intersex people, trans-sexuality, homosexuality, female pseudohermaphroditism, male pseudohermaphroditism, true hermaphroditism, testes and ovaries.

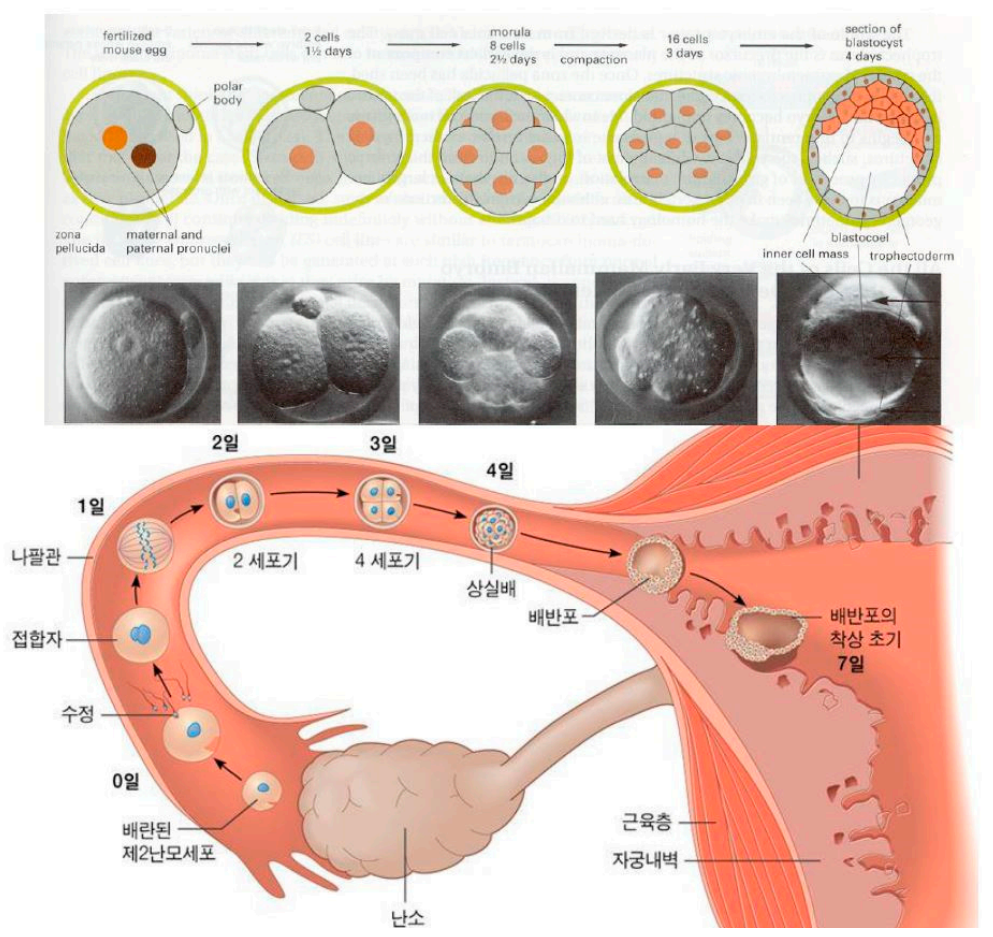

Figure 4. From ovulation to implantation (Prof. Ham Hoon Cho's class' slide).

With regard to life and birth, Cho emphasized the biological difficulty of cytodifferentiation and the mystery of the movement of fertilized eggs from ovulation to implantation on the wall of uterus over seven days. Likewise, the mysteries and secrets of birth are explained through medical knowledge. Kwon suggested that, from Kaufman's theological perspective, life and birth serve as new symbols for God as the whole grand cosmic evolutionary movement [37]. These new symbols overcome the limitations of anthropomorphic and anthropocentric conceptions of God, and emphasize the diversity of human life and theological discourse.

With regard to disease, suffering, death, and resurrection, Cho discussed medical issues, including the etymology of pathology, the International Classification of Disease, cardiovascular disorders, comparisons between normal livers and those with alcoholic cirrhosis, HeLa cell-immortal, cancer cells, TNM (Tumor, node and metastasis classification) staging and life expectancy (Figure 5), breast cancer, breast Ca TNM, the AJCC staging system, and the five-year survival rate for breast cancer, stages of breast cancer, the Kaplan-Myer Survival Analysis, determination of brain death, organ transplantation, euthanasia, mortality, myocardial infarction, organ necrosis, pink hypostasis, the similarities and differences between postmortem hypostasis and SQ hemorrhages, rigor mortis, postmortem cooling, temperature at the time of death, the equation for estimating the time of death, death-related forensic 
medical issues, fatal pressure on the neck, mtDNA and maternal inheritance, and the heterogeneity index STR as a factor of the number of tandem repeats of the Y-chromosome.

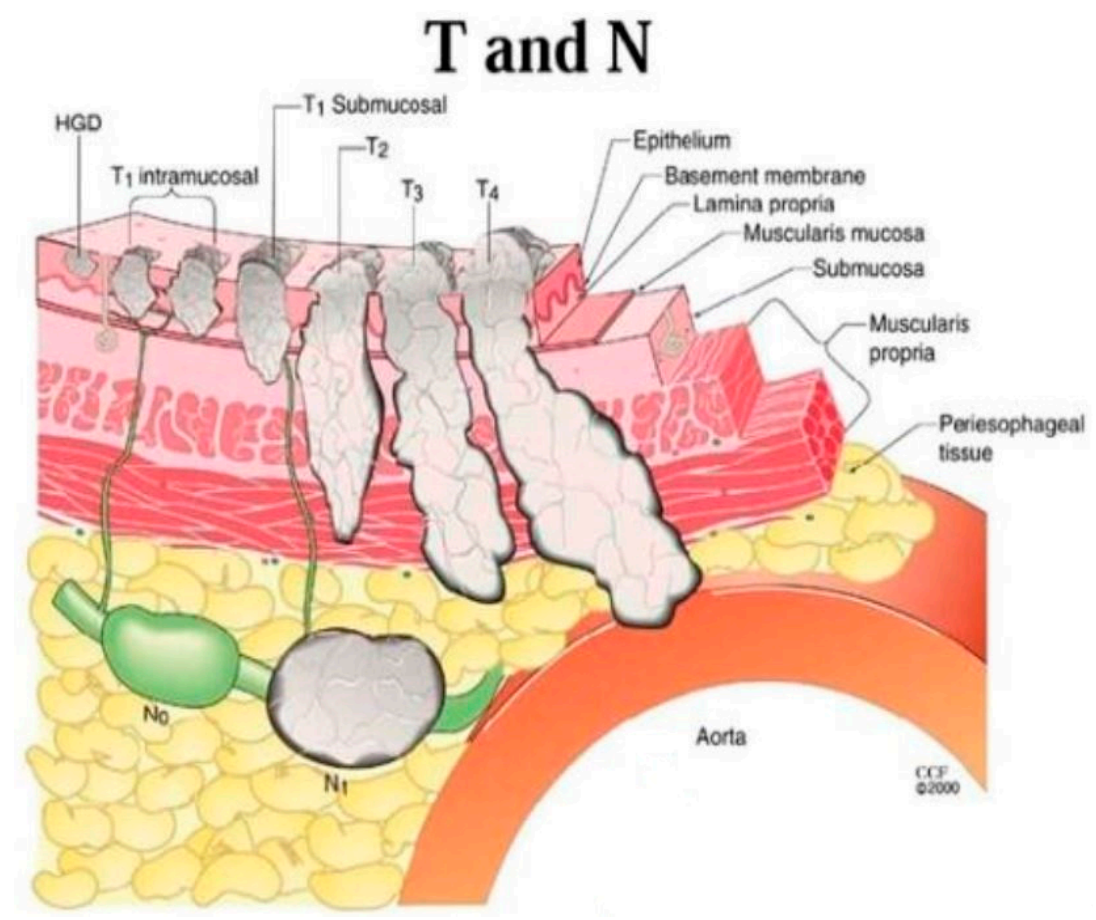

Figure 5. TNM staging and life expectancy (Prof. Ham Hoon Cho's class slide).

Medically, the relationship between TNM staging and life expectancy shows that the developmental process of disease corresponds to the progress of death and the mortality factors of normal cells. Theologically, disease and death are understood as an essential condition for experiencing union with God. In addition, the meaning of death was ascribed to God's creativity and as the main descriptive element of true humanity. Kwon emphasized reconstructing theological knowledge and re-imaging God to connect theological insights to other academic fields, such as medicine. Kwon's reimaging project for such theological construction can be found in his massive open online course entitled "Reimaging God in the Korean Context," supported by coursera.com (Figure 6).

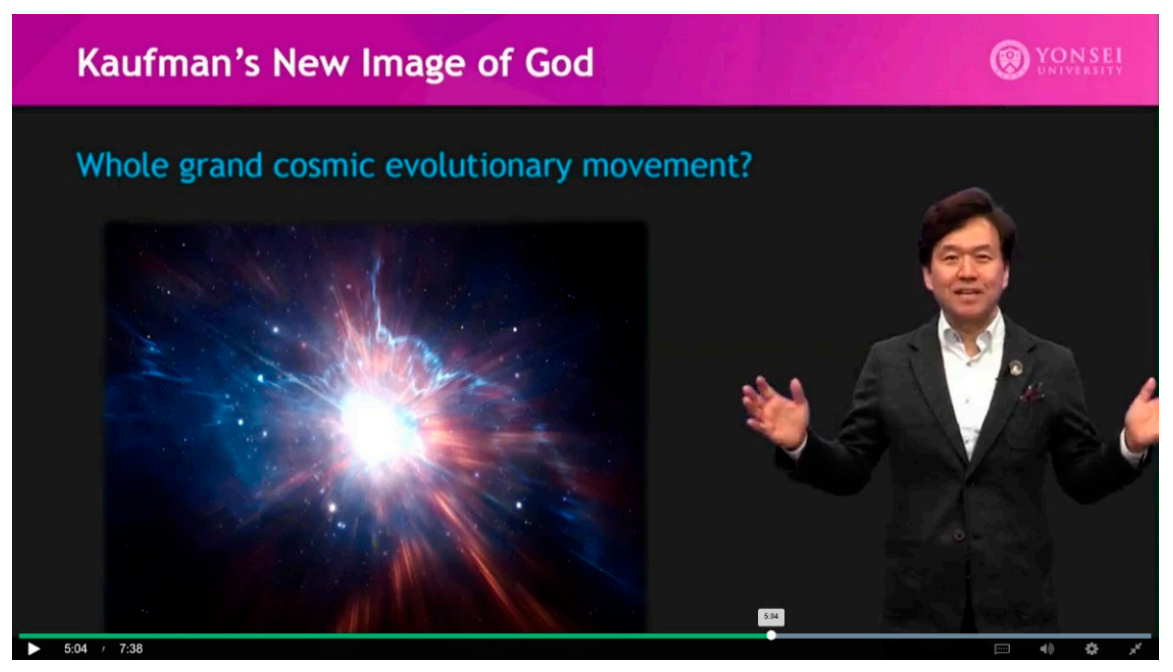

Figure 6. Professor Soo-Young Kwon's massive open online course, "Reimaging God in the Korean Context." (https:/ / www.coursera.org/learn/god-korean-context/lecture/sA1eO/theologyas-a-work-of-the-imagination). 
Professors Kwon's and Cho's lectures were supplemented by their students presentations on the following CEMT topics: surrogate mother sociopsychological suffering and its theological meaning, artificial insemination and its theological productive creativity, medical and theological reflections on infertile couples, medical and theological discourses on abortion, the donation of cadavers for medical research in the South Korean context, suffering and healing for elderly family caregivers, spiritual nurturing programs for cancer patients, dying well and providing spiritual care for the aged in society, Christian care for the parents of brain-dead babies, euthanasia for the chronically ill and aged and end-of-life care decisions, and pediatric hospice care for child cancer patients. The students' presentations showed how well a CMET perspective can supplement the respective shortcomings of medicine and theology.

\section{Conclusions}

The CEMT creators fully recognize that medicine and theology have distinct knowledge bases. However, they also consider the imaginative capacity of CEMT. It may be inevitable that religious education must field arguments regarding the rationality or probability of religious traditions in a secular society. The integrative narrative between medical science and theological understanding created by the CEMT can be a source of encouragement to both the faithful community and medical institutions in a secularized environment.

Author Contributions: S.-Y.K. and N.H.C. designed and in real class contexts practiced the CEMT and M.S. wrote the paper.

Funding: This work was supported by the Ministry of Education of the Republic of Korea and the National Research Foundation of Korea (NRF-2017S1A5A8022660).

Conflicts of Interest: The authors declare no conflicts of interest.

\section{References}

1. Taylor, C. A Secular Age; The Belknap Press of Harvard University Press: Cambridge, MA, USA, 2007; p. 423.

2. Habermas, J. The Theory of Communicative Action: Lifeworld and System; (T. McCarthy Trans.); Beacon Press: Boston, MA, USA, 1987; Volume 2, p. 289.

3. Boeke, J.D.; Church, G.; Hessel, A.; Kelley, N.J.; Arkin, A.; Cai, Y.; Carlson, R.; Chakravarti, A.; Cornish, V.W.; Holt, L.; et al. The genome project-write. Science 2016, 353, 126-127. [CrossRef] [PubMed]

4. DeFrancesco, L. Gene drive overdrive. Nat. Biotechnol. 2015, 33, 1019-1021.

5. Suresh, A. CRISPR Crisis: Is UK Researcher's Human Embryo Gene Editing Research Cause for Worry? Genetic Literary Project: North Wales, PA, USA, 2015. Available online: https://geneticliteracyproject.org/2015/10/ 27 / crispr-crisis-is-uk-researchers-human-embryo-gene-editing-research-cause-for-worry/ (accessed on 10 November 2018).

6. Baltimore, D.; Berg, P.; Botchan, M.; Carroll, D.; Charo, R.A.; Church, G.; Corn, J.E.; Daley, G.Q.; Doudna, J.A.; Fenner, M.; et al. A prudent path forward for genome engineering and germline gene modification: A framework for open discourse on the use of CRISPR-Cas9 technology to manipulate the human genome is urgently needed. Science 2015, 348, 36-38. [CrossRef] [PubMed]

7. Jackson, R. The interpretive approach as a research tool: Inside the REDCo project. In Religion, Education, Dialogue and Conflict: Perspectives on Religious Education Research; Jackson, R., Ed.; Routledge: New York, NY, USA, 2012; pp. 86-87.

8. Wielzen, D.R.; Avest, I.T. Introduction: Looking ahead at contested concepts and practices. In Interfaith Education for All: Theoretical Perspectives and Best Practices for Transformative Action; Wielzen, D., Avest, I.T., Eds.; Sense Publishers: Rotterdam, The Netherlands, 2017; pp. 2-3.

9. McGrath, A.E. A Fine-Tuned Universe: The Quest for God in Science and Theology; The 2009 Gifford Lectures; Westminster John Knox Press: Louisville, KY, USA, 2009; pp. 1-7, 11-12.

10. Dyson, F.J. Infinite in All Directions; Gifford lectures given at Aberdeen, Scotland, April-November 1985; HarperCollins Publishers: New York, NY, USA, 2004. 
11. Barrow, J.D. New Theories of Everything: The Quest for Ultimate Explanation; Oxford University Press: New York, NY, USA, 2007; p. 16.

12. Polkinghorne, J. The Faith of a Physicist: Reflections of a Bottom-Up Thinker; The Gifford Lectures for 1993-1994; Fortress Press: Minneapolis, MN, USA, 1996; p. 76.

13. Vogel, G. Embryo engineering alarm: Researchers call for restraint in genome editing. Science 2015, $347,1301$. [CrossRef] [PubMed]

14. Meyendorff, J. Byzantine Theology: Historical Trends and Doctrinal Themes; Fordham University Press: New York, NY, USA, 1983; pp. 67-77, 130, 141.

15. Hamalis, P. The meaning and place of death in an Orthodox ethical framework. In Thinking through Faith: New Perspectives from Orthodox Christian Scholars; Papanikolaou, A., Prodromou, E.H., Eds.; St. Vladimir's Seminary Press: New York, NY, USA, 2008; pp. 183-217.

16. Johnson, S. Christian Spiritual Formation in the Church and Classroom; Abingdon Press: Nashville, TN, USA, 1989; p. 117.

17. Schmemann, A. For the Life of the World: Sacrament and Orthodox, 2nd ed.; St. Vladimir's Seminary Press: New York, NY, USA, 1973; pp. 18, 44.

18. Ware, T. The Orthodox Church: An Introduction to Eastern Christianity; Penguin Books: London, UK, $2015 ;$ p. 58.

19. Reardon, S. Gene-editing wave hits clinic: Companies prepare to test range of therapies in people. Nature 2015, 527, 146-147. [CrossRef] [PubMed]

20. Hamalis, P. The theological-ethical contributions of Archimandrite Sophrony (Sakharov) to environmental issues. In Toward an Ecology of Transfiguration: Orthodox Christian Perspectives on Environment, Nature, and Creation; Chryssavgis, J., Foltz, B.V., Eds.; Fordham University: New York, NY, USA, 2013; p. 126.

21. Delkeskamp-Hayes, C. Rethinking the Christian bioethics of human germ line genetic engineering: A postscript against the grain of contemporary distortions. Christ. Bioeth. 2012, 18, 219-230. [CrossRef]

22. Hamalis, P. Ethics. In The Orthodox Christian World; Casiday, A., Ed.; Routledge: London, UK; New York, NY, USA, 2012; p. 429.

23. Koios, N. Theological anthropology and human germ-line intervention. Christ. Bioeth. 2012, 18, $187-200$. [CrossRef]

24. Harakas, S.S. Bioethics in Eastern Orthodox Christianity. In Encyclopedia of Bioethics; Post, S.G., Ed.; Macmillan Library Reference: New York, NY, USA, 2003; pp. 691-697.

25. Hamalis, P. Public theology. In The Encyclopedia of American Religion and Politics; Djupe, P.A., Olson, L.R., Eds.; Facts on File, Inc.: New York, NY, USA, 2003; p. 344.

26. Engelhardt, H.T., Jr. Genetic enhancement and theosis: Two models of therapy. Christ. Bioeth. 1999, 5, 197-199. [CrossRef] [PubMed]

27. The Korea Herald. Ebola Death Toll Passes 3000. 28 September 2014. Available online: http://www. koreaherald.com/view.php?ud=20140928000053\&ACE_SEARCH=1 (accessed on 10 November 2018).

28. Reardon, S. Ebola treatments caught in limbo. Nature 2014, 511, 520. [CrossRef] [PubMed]

29. Hayden, E.C. World struggles to stop Ebola. Nature 2014, 512, 355-356. [CrossRef] [PubMed]

30. Butler, D. Ebola drug trials set to begin amid crisis. Nature 2014, 513, 13-14. [CrossRef] [PubMed]

31. Qiu, X.; Wong, G.; Audet, J.; Bello, A.; Fernando, L.; Alimonti, J.B.; Fausther-Bovendo, H.; Wei, H.; Aviles, J.; Hiatt, E.; et al. Reversion of advanced Ebola virus disease in nonhuman primates with ZMapp. Nature 2014, 512, 47-53. Available online: http:/ / www.nature.com/nature/journal/vnfv/ncurrent/full/nature13777. html (accessed on 29 August 2014). [CrossRef] [PubMed]

32. Alexander, D.R. The Language of Genetics: An Introduction; Templeton Science and Religion Series; Templeton Press: West Conshohocken, PA, USA, 2011; pp. 24-28.

33. Collins, F.S. The Language of God: A Scientist Presents Evidence for Belief; Free Press: New York, NY, USA, 2006; p. 104.

34. Nowak, M.A.; Coakley, S. Introduction: Why cooperation makes a difference. In Evolution, Games, and God: The Principle of Cooperation; Nowak, M.A., Coakley, S., Eds.; Harvard University Press: Cambridge, MA, USA, 2013; pp. 1-34.

35. Coakley, S. Cooperative, Alias Altruism: Game Theory and Evolution Reconsidered. Sacrificed Regained: Evolution, Cooperation and God; The Gifford Lectures; University of Aberdeen: Aberdeen, UK, 2012. Available online: http:/ / www.abdn.ac.uk/gifford/documents/Gifford_Lecture_2_-_lecture_text.pdf (accessed on 12 September 2013). 
36. Browning, D.S. Equality and the Family: A Fundamental, Practical Theology of Children, Mothers, and Fathers in Modern Societies; William B. Eerdmans Publishing Company: Grand Rapids, MI, USA, 2007.

37. Kaufman, G.D. Jesus and Creativity; Fortress Press: Minneapolis, MN, USA, 2006.

(c)

(C) 2018 by the authors. Licensee MDPI, Basel, Switzerland. This article is an open access article distributed under the terms and conditions of the Creative Commons Attribution (CC BY) license (http:/ / creativecommons.org/licenses/by/4.0/). 